\title{
İlköğretim Matematik Öğretmeni Adaylarının Seçilen Zekâ ve Mantık Sorularını
}

\section{Çözme Stratejilerinin Belirlenmesi}

\section{Mithat TAKUNYACI*}

Öz: Soyut bir ders olan matematik; öğrencilere nesneler arasındaki ilişkileri kavrayabilme, soyut düşünebilme, muhakeme edebilme ve bu zihinsel işlevleri uyumlu şekilde bir amaca yönelik olarak kullanabilme yeteneklerini kazandırmayı hedeflemektedir. Öğrencilerin var olan bu yeteneklerinin ortaya çıkması ya da geliştirilmesi zekâ ve mantık soruları/oyunlarıyla sağlanabilir. Çalışmanın amacı, ilköğretim matematik öğretmen adaylarının zekâ ve mantık sorularını çözerken kullandıkları stratejileri belirlemek ve sınıflandırmaktır. Bu amaç doğrultusunda ilköğretim matematik öğretmenliği son sınıfta öğrenim görmekte olan 34 öğretmen adayı ile çalışma yürütülmüşsür. Çalışmada belirli bir durum incelendiği için nitel araştırma yöntemlerinden durum çalışması modeli kullanılmıştır. Veri toplama aracı olarak Bulut (2013) tarafından yayınlanan "Eğiten, Düşündüren ve Geliştiren Zekâ Soruları" kitabından çalışmanın amacına uygun 5 adet soru ve bu soruların değerlendirilmesinde Ergün (2018) tarafından geliştirilen "Zekâ Oyunları Dersine Yönelik Öğretmen Görüş Anketi” araştırmacı tarafından çalışmaya uyarlanarak kullanılmıştır. Verilerin analizinde; nitel veri analizi tekniklerinden, betimsel analiz ve içerik analizi kullanılarak yüzde-frekans değerleri hesaplanmış ve yorumlanmıştır. Elde edilen bulgulara göre öğretmen adaylarının zekâ ve mantık sorularını çözerken öğretmen adaylarının en çok denklem kurma stratejisini tercih ettikleri, daha sonrasında deneme-yanılma ve şekil, tablo, resim vb. çizme ve problemi basitleştirme stratejilerini tercih ettikleri bulunmuştur.

Anahtar Kelimeler: Zekâ ve mantık soruları, matematik oyunları, matematik öğretimi

\section{Investigation of Prospective Mathematics Teachers’ Intelligence and Logical Questions Solving Skills}

Abstract: Mathematics, which is an abstract lesson, aims to enable students to comprehend relationships between objects, think abstractly, reason, and use these mental functions harmoniously. The emergence or development of these current abilities of students can be achieved through intelligence and logic questions / games. The aim of study is to determine and

\footnotetext{
* Dr. Öğretim Üyesi, Sakarya Üniversitesi, Eğitim Fakültesi Matematik Eğitimi, Email: mtakunyaci@sakarya.edu.tr, Orcid No: 0000-0003-1065-975X.
} 
classify the mental functions used by prospective mathematics teacher in solving intelligence and logic questions. For this purpose, the study was carried out with 34 prospective mathematics teachers who were studying at senior level. Since a specific situation is examined in the study, the case study model, which is one of the qualitative research methods, was employed. As a data collection tool, 5 questions from the book as called "Eğiten, Düşündüren ve Geliştiren Zekâ Soruları" published by Bulut (2013) were found to be suitable for the purpose of the study, and the "Teacher Opinion Survey for the Intelligence Games Lesson" developed by Ergün (2018) was adapted to the study by the researcher. In the analysis of the data, percentagefrequency values were calculated and interpreted using the descriptive analysis and content analysis technique. According to the findings, the pre-service teachers mostly preferred the strategy of establishing equations while solving the intelligence and logic questions. Moreover, it was determined that they preferred drawing and problem simplification strategies.

Keywords: Intelligence and logical questions, math games, mathematics teaching

\section{Giriş}

Uluslararası Matematik ve Bilim Çalışmalarındaki Eğilimler (TIMSS) ve Uluslararası Öğrenci Değerlendirme Programı'ndan (PISA) elde edilen veriler, Türkiye’ nin matematik okuryazarlığında geride kalmaya devam ettiğini göstermektedir (Ulusal Eğitim İstatistikleri Merkezi [NCES], 2018). Müfredata dayalı içerik bilgisinden ziyade konu alanlarındaki okuryazarlığı ölçmek için tasarlanan PISA, öğrencilerin konu alanlarındaki bilgilerini diğer bağlamlarda problem çözme için kullanma yeteneklerini hedeflemektedir (NCES, 2018; Pope, Brown ve Miles, 2015). 2018 PISA sonuçları, Türkiye’nin matematik başarısı sıralamasında 42. ve okuduğunu anlamada ise 40. sırada olduğunu göstermektedir (NCES, 2018). Ayrıca, bu puanlar 2006, 2009, 2012 ve 20015 yıllarında yapılan PISA sınav puanlarından farklı olmadığ1 için yıllar içinde herhangi bir gelişmenin kaydedilmediği görülmektedir (NCES, 2018). Aynı zamanda bu sonuçlar, ülkemizdeki eğitim reformlarının ve uygulanan çeşitli standartların yeterli düzeyde olmadığını ifade etmektedir.

21. yüzyıl öğrenme çıtıları, öğrencilerin matematik kavramlarını derinlemesine kavradıklarında ve matematiğin uygulamaları olarak sınıf dışındaki sorunları çözmek için mantıksal düşünmeyi kullandıklarında gerçekleşmektedir (Sanders, 2012). John Dewey, mantıksal düşünmeyi "herhangi bir inancın veya sözde bilgi biçiminin, onu destekleyen gerekçeler ve eğilim gösterdiği diğer sonuçlar 1şığında aktif, ısrarcı ve dikkatli bir şekilde 
değerlendirilmesi” olarak tanımlamıştır (Cumming, 2014). Mantıksal düşünme, ilk olarak 1958’ de Piaget ve Inhelder tarafından incelenmiş ve mantıksal muhakeme yeteneğinin gelişimi ergenlerde ve yetişkinlerde geniş çapta araştırılmıştır (Tobin ve Capie, 1981). Bu araştırmaların bulguları, birçok ergen ve yetişkinin mantık ve akıl yürütme biçimlerini kullanma becerilerinin sınırlı olduğunu göstermiştir (Tobin ve Capie, 1981). Piaget’ e (1958) göre, bir çocuk, 11 veya 12 yaşında, matematiksel işlem yapabilme aşamasına geçtiğinde, bir işlemin çözümünü inancına göre yargılamak yerine mantıksal geçerliliğine göre yargılamaktadır (Sharpiro ve O’Brien, 1970).

Birçok araştırma, ortaokul, lise ve üniversitede öğretilen matematik ve fen kavramlarının çoğunun öğrenilmesi için düşünmenin gerekli olduğunu göstermektedir (Tobin ve Capie, 1982). Ayrıca araştırmalar, ortaokul ve liselerdeki öğrencilerin çoğunun problem çözmede formal işlemlerini kullanamadığını ve bu nedenle eğitimde önceliğin, öğrencilerin problem çözme ve muhakeme yeteneklerinin geliştirilmesine verilmesi gerektiğini vurgulamışlardır (Tobin ve Capie, 1982).

Birçok araştırmacı problem çözmenin bir karar verme süreci olduğu konusunda birçok araştırmacı ortak düşünceye sahiptir (Hayes, 1989; Martinez, 1998; Reeff, 1999). Altun (2005) problem çözmeyi, "Ne yapılacağının bilinmediği durumlarda yapılması gerekeni bilmektir." şeklinde ifade etmiştir. Problem çözme yalnızca bir doğru sonuç bulma olarak algılanmakla birlikte daha kapsamlı bir zihinsel süreci ve becerileri kapsayan bir eylemdir (Sweller, Clark ve Kirschner, 2010). Önemli olan bir problemle karşılaşıldığında onun anlaşılmasıdır (Lowrie ve Logan, 2006). Kişi eğer problemi anlayamazsa bu problem için çözüm öneremez ve çözüm için stratejiyi ortaya çıkarma ve uygulamada zorluk yaşar (Heppner ve Krauskopf, 1987). Bu nedenle problem çözme süreci; "net olarak tasarlanan fakat hemen ulaşılamayan bir hedefe varmak için kontrollü etkinliklerle araştırma yapma” şeklinde açıklanabilir (Altun, 2016). Martinez (1998) ve Hayes (1989) problem çözmeyi, sorunun doğasının tanınmasını, başarıyı açıklayan son durumun tanımlanmasını, mevcut durumdan son duruma gitmek için bir strateji oluşturulmasını ve stratejinin yürütülmesini (karşılaşılan zorluklara dayalı olarak strateji değişikliklerinin uyarlanmasını) gerektiren hedef odaklı bir süreç olarak tanımlamışlardır. Bir problem gerçek dünya bağlamına dayandığında, bir problem çözücüsü tarafından problemin tanınmasının ve anlaşılmasının algılanması, uygun stratejilerin seçilmesi problemi çözmek için bir süreç tasarlamanın anahtarıdır (Reeff, 1999).

Stratejiler, bir sorunu çözmek için tasarlanmış zihinsel veya fiziksel eylem gruplarıdır (Biddlecomb ve Carr, 2011). Öğrencilerin bir problemin doğru cevabını bulmak için 
kullanabilecekleri birçok strateji vardır ve bu stratejileri bilmeleri ve kullanmaları gerekmektedir. Matematik öğrenirken öğrenciler problemin çözümüne ulaşmanın bir yolunu kendi başlarına keşfetme fırsatına sahip olmalıdır (Cotic ve Zuljan, 2009). Öğrenciler problem çözme için stratejileri nasıl doğru kullanacaklarını öğrendikleri zaman ortaya çıkabilecek herhangi bir problemi daha iyi çözebilirler. “John Dewey, bir konuyu daha derinden anlamanın en iyi yolunun, sorunları çözmek için daha iyi yöntemler aramak olduğuna işaret etmektedir.” (Stanic ve Kilpatrick, 1988). Bu daha iyi yöntemler veya stratejiler, öğrencilerin matematik problem çözme sürecini tamamlamalarına yardımcı olmayı sağlayacaktır. Öğretmenler stratejileri tam olarak ve açıkça öğrettiklerinde, öğrencilerin stratejileri içselleştirmeleri ve arka plan bilgisi haline getirmeleri üzerinde olumlu bir etkisi olduğunu bilinmektedir (Biddlecomb ve Carr, 2011). Öğrenciler, öğrenilen yeni yöntemi ya da stratejiyi matematiksel bir kelime problemine uygulayana ve çözümü bulmada başarılı olana kadar yeni stratejilerin değerini bilemeyebilirler (Cotic ve Zuljan, 2009). Çözüm için öncelikle problemin iyi anlaşılmış olması gerekmektedir. Problem çözümü için uygun stratejinin belirlenebilmesi, problemi anlamaya ve stratejileri tanımaya bağlıdır. Bazı problemlerin çözümünde bazen bir, bazen birkaç strateji birlikte kullanılır. Bazen de aynı problemin çözümüne farklı stratejiler uygun gelebilir (Akay, 2006). Literatürde problem çözme stratejilerinden en çok kullanılanlarından bazıları şunlardır:

> Resim/şema/model çizme stratejisi: Bir resim/şema/model çizmek, en yaygın problem çözme stratejisidir. Çoğu zaman, öğrencilerin sadece sorunu anlamak için bir resim/şema/model çizmeleri gerekir. Resim/şema/model, öğrencilerin problemi “görebilecekleri”, “anlayabilecekleri” ve bir sonraki adımı ararken üzerinde düşünebilecekleri şekilde problemi temsil eder.

$>$ Bă̆ıntı, örüntü arama stratejisi: Öğrenciler bu problem çözme stratejisini kullandıklarında, verilerdeki kalıpları analiz etmeleri ve analizlerine dayalı olarak tahminler ve genellemeler yapmaları gerekmektedir. Daha sonra, problemdeki bilgilere karşı genellemeyi kontrol etmeli ve muhtemelen verilen bilgilerden bir tahminde bulunmalı veya verilen bilgilerin uzantısını yapmalıdırlar. Bir model sayısal, görsel veya davranışsal olabilir. Örüntüleri tanımlayarak, öğrenciler bir sonraki adımda neyin geleceğini tahmin edebilirler.

> Problemi canlandırma stratejisi: Öğrenciler, bir problemi veya çözümü için gerekli prosedürü görselleştirmede zorluk yaşadıkları zamanlarda, problem durumunu fiziksel olarak canlandırmayı yararı bulabilirler. Problemi canlandırmak, öğrencileri cevaba 
yönlendirebilir veya cevabı bulmalarına yardımcı olacak başka bir strateji bulmalarına yol açabilir.

$>$ Geriye doğru çalışma stratejisi: Geriye doğru çalışma stratejisinde sonuçtan yola çıkarak ve adım adım verileri yok ederek, ilk veriye ulaşmaya çalışılır. Bu süreçte en başa varıldığında, aranan değere ulaşılmış olmalıdır.

> Tahmin ve doğrulama stratejisi: $\mathrm{Bu}$ strateji, öğrencileri mantıklı bir tahminde bulunmaya, tahmini kontrol etmeye ve gerekirse tahminini gözden geçirmeye teşvik eder. $\mathrm{Bu}$ işlemi tekrarlayarak öğrenci, kontrol edilmiş doğru bir cevaba ulaşabilir. $\mathrm{Bu}$ stratejiyi kullanmak her zaman hemen doğru bir çözüm getirmez, ancak sorunu daha iyi anlamak için kullanılabilecek bilgiler sağlar ve başka bir stratejinin kullanılmasını önerebilir.

Sistematik liste yapma stratejisi: Liste veya tablo yapmak, bir problemde sunulan verileri düzenlemenin bir yoludur. Bu problem çözme stratejisi, öğrencilerin veriler arasındaki ilişkileri ve kalıpları keşfetmelerini sağlar. Bu strateji, öğrencilerin matematiklerine mantıklı ve sistematik bir gelişim getirmelerine yardımcı olur.

Mantıksal akıl yürütme stratejisi: Bu strateji, tüm problem çözümleri için kullanılabilir. Birçok yönden, öğrenciler bu strateji kategorisini her şeyi ortaya çıkarma olarak kullanırlar çünkü bu stratejiler genellikle kendi başlarına değil, yukarıda bahsedilen diğer stratejilerle birlikte kullanılır. Ayrıca insanların günlük hayatta sıkça kullandığı eleme stratejisini de ifade etmektedir. Problem çözme bağlamında, öğrencilerin problemde sunulan bilgilere dayalı olarak olası çözümleri listelemelerini ve ortadan kaldırmalarını sağlamaktadır.

> Uç durumları düşünme stratejisi: Bazı sorularda en uçtaki örneklere bakmak soruların çözümünde yarar sağlar. Bazı değişkenler sabit tutulup diğer değişkenleri en uzak ve uç değerlere sahip olması verilen durum için kullanışı bir bakış açısı kazandırır.

> Daha basit ve benzer bir problem üzerinde düşünme stratejisi: Bu strateji, içerdiği büyük sayılar ve karmaşık bağıntılar nedeniyle çözülemeyen bir problemin daha küçük sayıları içeren bir modelini çözme ve bu modellerin arasındaki ilişkiden faydalanarak çözüme ulaşma şeklinde bir çalışma gerektirir.

> Değişken kullanma (Denklem kurma) stratejisi: Aritmetik ve cebir problemlerinin birçoğu, bilinmeyen bir sayının bulunmasını ister. Bilinmeyen yerine değerler konarak çözüm bulunabilir. Ancak bazen denenmesi gereken değer o kadar çok olur ki denemeyle başa çıkılamayabilir. Bazen de problem bir genellemeyle ilgili olur ve 
örneklerin denenmesi çözüm için yeterli olmaz. Böyle durumlarda bilinmeyeni x gibi bir harfle gösterip denklem ya da eşitsizlik kurmak ve çözmek suretiyle istenen cevaba ulaş1lır (Altun, 2005; Fan ve Zhu, 2007).

Matematik öğrenmek, öğrencilerin eleştirel düşünme, mantıksal, sistematik ve nesnel nitelikte, dürüst, disiplinli ve çeşitli alanlarda problem çözme becerilerini yansıtan akıl yürütme becerilerini oluşturmayı amaçlamaktadır (Widdiharto, 2004). Matematik, günlük yaşamdaki problemleri çözmek için kullanılabilecek matematiksel, mantıksal, sistematik ve eleştirel bir zihniyete dönüşebilir. Bu görüş doğrultusunda matematiğin, matematik eğitiminin doğası ile ilgili iki gelişme yönü vardır; biri günümüzün ihtiyaçlarına yönelik gelişme, diğeri de matematik ve diğer bilimlerin problemini çözmek için ihtiyaç duyulan kavramların anlaşılmasına, mantıksal, sistematik, eleştirel düşünme, dikkatli, nesnel ve açık olma yeteneklerine yönelik gelişmedir (Sumarmo, 2002). Matematik ile ilgili programlarda yer alan dersler aracılığıyla analiz, eleştirel akıl yürütme, mantıksal düşünme, problem çözme, iletişim ve matematiksel temsil yeteneğinin gelişimi sağlanmaktadır (Committee on the Undergraduate Program in Mathematics [CUPM], 2004). Bu nedenle, matematik öğretiminden sorumlu öğretmen adayları (öğretmenler) ve okullar, öğrenciyi matematiksel beceriyi geliştirmeye hazırlamaktan sorumludur, çünkü matematik eğitiminde ulusal ve uluslararası başarıya ve başarısızlığa neden olan faktörlerden birisinin de eğitimciler olduğunu söyleyebiliriz.

Öğretmen adayları olarak matematik eğitimi alan öğrenciler (öğretmenler), gelecek neslin sadece beyin zekasına değil, aynı zamanda iyi bir karaktere sahip bir ulusun oluşumunda stratejik bir role sahip olduklarının farkında olmalıdır. Bu durumda zekâ göstergeleri olan mantıksal ve eleştirel düşünme becerilerinin, öğretmen adaylarında geliştirilmesi gerekmektedir (The National Council of Teachers of Mathematics [NCTM], 2000).

Mantıksal düşünme yeteneğinin, problem çözme etkinlikleri ile yakından ilgili olduğunu söyleyebiliriz. Mantıksal düşünme yeteneği ile problemi çözmek, genelleme veya soyutlama yaparak ilke veya kurallara ulaşmaktır (Yaman, 2005). Bu nedenle, öğrencilerin mantıksal düşünme yeteneği; öğrencilerin, problem çözme, yaratıcı düşünme, eleştirel ve yansıtıcı gibi kritik beceriler gerektiren bazı etkinlikler yapmalarıyla geliştirilebilir. Öğrenciler, problem çözme etkinliklerine ne kadar sık dahil olurlarsa, mantıksal düşünme yetenekleri de o derecede iyileşebilir.

Zekâ soruları ve oyunları, içerdiği gerçek problem durumları karşısında çocukların düşünme becerilerini ve kendilerine özgü stratejilerini kullanarak zihinsel etkinliklerle eğlenerek problem çözmenin en etkili yoludur (Alessi ve Trollip, 2001; Bottino, Ferlino, Ott, 
Tavella, 2007). Böylelikle çocukların zihinsel becerilerine katkı sağlamak, ilk kez karşılaştıkları problemler karşısında özgün ve yeni çözüm yolları oluşturabilmelerini sağlamak zekâ soruları ve oyunları sayesinde mümkündür (Intaros, Inprasitha ve Srisawadi, 2014).

\section{Çalışmanın önemi ve amacı}

Soyut bir ders olan matematik; öğrencilerde nesneler arasındaki ilişkileri kavrayabilme, soyut düşünebilme, muhakeme edebilme ve bu zihinsel işlevleri uyumlu şekilde bir amaca yönelik olarak kullanabilme yeteneklerini kazandırmayı hedeflemektedir (Nesin, 1989; Pesen ve Odabaş, 2000). Öğrencilerin var olan bu yeteneklerinin ortaya çıkması ya da geliştirilmesi zekâ ve mantık soruları/oyunları ile sağlanabilmektedir. Bu yüzden araştırmanın amacı, ilköğretim matematik öğretmen adaylarının seçilen zekâ ve mantık sorularını çözerlerken kullandıkları stratejileri belirlemek ve sınıflandırmaktır.

\section{Çalışmanın problemi}

- İlköğretim matematik öğretmeni adaylarının zekâ ve mantık sorularını sınıflandırmaları (Bilgi düzeyini ölçen, önem derecesi, kullanma sıklığı) nasıldır?

- İlköğretim matematik öğretmeni adaylarının zekâ ve mantık sorularını çözerken kullandıkları stratejileri nelerdir?

\section{Yöntem}

\section{Çalışmanın Modeli}

Öğrencilerinin zekâ sorularını çözerken Polya' nın (1973) problem çözme stratejilerinin hangilerini kullandıklarının belirlenmesini hedefleyen bu çalışmada nitel araştırma yöntemi kullanılmıştır. Nitel araştırma; nitel veri toplama yöntemlerinin kullanıldığı, konuların ve olayların doğal ortamda bir bütün şeklinde ortaya konulmasına yönelik ilerleyen bir süreç olarak tanımlanmaktadır (Yıldırım ve Şimşek, 2008). Araştırmaya konu olan öğretmen adaylarının zekâ sorularını çözerken kullandıkları problem çözme stratejilerinin neler olduklarının belirlenmesi nitel araştırma yönteminin kullanılmasını gerekli kılmıştır.

Araştırmada belirli bir grup matematik öğretmeni adaylarının zekâ sorularını çözme durumlarının incelenmesi amaçlandığından ve sonuçların sadece bu gruba özgü olmasından dolayı nitel araştırma yöntemlerinden durum çalışması (case study) deseni kullanılmıştır. Durum çalışmalarında temel amaç, faaliyetlerin, kararların ve insan etkileşimlerinin kapsamlı bir şekilde karmaşıklığını yakalamaktır (Stake, 1995). Ayrıca durum çalışması bireysel olarak 
yürütülen çalışmalara uygun olmasının nedeni “Ne?”, “Nasıll?” ve “Niçin?” sorularının cevaplarını içerir (Çepni, 2009). Araştırmada süreç içerisinde nasıl ve niçin sorularına cevap aranması, seçilen araştırma modelini destekler niteliktedir.

\section{Çalışma Grubu}

Durum çalışmalarında örneklem; amaçl1, seçici, teorik gibi farklı yollarla seçilebilmektedir (Yıldırım ve Şimşek, 2008). Bu bağlamda çalışmada amaçlı örnekleme yöntemlerinden kolay ulaş1labilir olma ve ölçüt örnekleme yöntemleri kullanılmıştır. Çalışmaya katılacak öğretmen adaylarının seçiminde, adayların "Zekâ soruları Yardımı ile Matematik Öğretimi” dersini alma temel ölçüt olarak belirlenmiştir. Bu temel ölçüt gereğince çalışmanın ilk aşaması Sakarya Üniversitesi Eğitim Fakültesi Matematik ve Fen Bilimleri Eğitimi Bölümü İlköğretim Matematik Öğretmenliği bünyesinde öğrenim gören ve 2019-2020 Eğitim-Öğretim yılı bahar yarıyılında “Zekâ soruları Yardımı ile Matematik Öğretimi” dersine kayıt yaptıran 34 öğretmen adayı ile yürütülmüştür.

Tablo 1. Çalışma Grubunun Cinsiyete Göre Dağılımı

\begin{tabular}{rcc}
\hline Cinsiyet & N & \% \\
\hline K1z & 29 & 85 \\
Erkek & 5 & 15 \\
\hline
\end{tabular}

Araştırmaya katılacak olan öğretmen adayları, araştırmacının aynı zamanda derslerine girdiği sınıftan seçilmiştir. Çünkü araştırmada belirlenen özel durumun, araştırmacının dersine girdiği sınıfta daha rahat ve detaylı olarak incelenebileceğine imkân sağlayacağı düşünülmüştür.

\section{Veri toplama araçları}

Çalışmada veri toplama aracı olarak Bulut (2013) tarafından yayınlanan "Eğiten, Düşündüren ve Geliştiren Zekâ Soruları” kitabından çalışmanın amacına uygun (özellikle farklı problem çözme stratejilerinin kullanıldığı) olarak 20 soru seçilerek soru havuzu oluşturulmuştur. Alan uzmanlarının görüşleri doğrultusunda soru sayısı, 5' e düşürülmüştür (Tablo 1). Ayrıca, bu soruların değerlendirilmesinde Ergün (2018) tarafından geliştirilen "Zekâ Oyunları Dersine Yönelik Öğretmen Görüş Anketi” araştırmacı tarafından çalışmaya uyarlanarak kullanılmıştır. Ankette, zekâ sorularının bilgi düzeyini ölçmedeki derecesi, önem 
derecesi ve kullanım sıklıkları 5' li likert tipinde (1-Hiç, 2-Az, 3-Orta, 4-Çok, 5-Olduk çok) sorulmuştur (EK 1).

Zekâ sorularının ve anketin kapsam (içerik) geçerliği uzman görüşü yöntemi ile yapılmıştır. Zekâ soruları ve anket soruları, 5’i matematik öğretmeni, 5’i de İlköğretim Matematik Eğitimi Programı öğretim üyesi olmak üzere alanında uzman toplam 10 kişi tarafından değerlendirilmiştir. Uzman kişiler, zekâ sorularını ve anket maddelerini "1-Hiç Uygun Değil 2-Çok düzeltilmesi gerekir 3- Az düzeltilmesi gerekir 4-Çok Uygun” şeklinde değerlendirmiş, değerlendirme sonunda gerekli düzenlemeler yapılmıştır. Uzman görüşünün değerlendirilmesinde, kapsam geçerliği indeksi kullanılmıştır. Ölçeğin kapsam geçerliği indeksi, uzman görüşleri $(\mathrm{n}=10)$ doğrultusunda Kendall's W testi ile yapılmıştır. Uzman görüşleri arasında istatistiksel olarak anlamlı fark bulunmamıştır (zekâ soruları için hesaplanan Kendall’s W = .17; p = .12; anket için hesaplanan Kendall's W = .32, p = .23).

Çalışmanın güvenirliği ve veri toplama aracının kullanışlılığını görmek amacıyla 10 öğrenciyle pilot çalışma yapılmıştır. Pilot çalışma sonunda bir ders saatinin yeterli olduğuna ve problemlerin öğrenciler tarafından anlaşılır olduğuna karar verilmiştir.

Tablo 1. Çalışmada sorulan zekâ soruları

\begin{tabular}{|c|c|}
\hline $\begin{array}{l}\text { ECZACININ } \\
\text { DAMACANALARI }\end{array}$ & $\begin{array}{l}\text { Eczacının } 16,18,22,23,24,34 \text { litrelik olmak üzere } 6 \text { adet damacanas } 1 \\
\text { var. Bunların bazılarına damıtı su ve kalanların biri hariç hepsine } \\
\text { alkol koydu. Kullandığ } 1 \text { alkol hacmi suyun iki katı idi. Hangi } \\
\text { damacana kullanılmadı? Hangilerine alkol, hangilerine su konuldu? }\end{array}$ \\
\hline $\begin{array}{l}\text { IRMAK } \\
\text { KIYISINDAKI İKİ } \\
\text { KUŞ }\end{array}$ & $\begin{array}{l}\text { Irmağın iki kıyısında birer hurma ağacı var, biri } 30 \mathrm{~m} \text {, diğeri } 20 \mathrm{~m} \\
\text { yükseklikte. Ağaçların dipleri arasındaki uzaklık } 50 \mathrm{~m} \text {. Her iki ağacın } \\
\text { tepesinde birer kuş var. Birden iki kuş da ırmakta bir balık görüp } \\
\text { üzerine uçuyor ve aynı zamanda balığa varıorlar. Uzun hurma } \\
\text { ağacının balığa olan uzaklığını bulunuz. }\end{array}$ \\
\hline İŞÇİLER & $\begin{array}{l}\text { Adam tarlasında çalıştırmak için amele tutacaktır. Erkeklerin } \\
\text { yevmiyesi } 5 \text { lira, kadınların yevmiyesi } 1 \text { lira ve çocukların yevmiyesi } \\
5 \text { kuruştu. Adam } 100 \text { amele tuttu ve gün sonunda toplam } 100 \text { lira } \\
\text { ödedi. Adam her gruptan kaç kişi tutmuştur? (Her gruptan en az } 1 \text { kişi } \\
\text { olmak zorunda.) }\end{array}$ \\
\hline
\end{tabular}


"Doğrucular" sürekli doğru, "Yalancılar" sürekli yalan, "Belirsizler" ise gelişigüzel bir biçimde bazen doğru bazen yalan söylemektedir. Doğrucu, yalancı ya da belirsiz grubundan olan A, B, C ve D'nin yaptıkları önermelere göre her birinin hangi gruptan olduklarını DOĞRU-YALAN bulunuz.

Not: Her gruptan en az 1 kişi bulunmaktadır.

A: Doğrucuların sayısı yalancılardan azdır.

B: A'nın son söylediği doğrudur.

C: A doğrucudur.

D: C'nin son söylediği doğrudur.

Ünal Bey $40 \mathrm{~km}$. mesafedeki şehre gitmek için otomobil kiralıyor. Yarı yolda iki arkadaşı daha biniyor ve son $20 \mathrm{~km}$. yi birlikte

KIRALIK OTOMOBILL gidiyorlar. Akşam da arkadaşlarıyla birlikte dönüyor ve arkadaşlarını aynı yerde indiriyor. Daha sonra Ünal Bey otomobili kiraladı ̌̆ı yere getiriyor ve 24 TL ödüyor. Ünal Bey ve arkadaşlarının masrafı mesafeye göre bölüşmeleri için kaçar lira vermeleri gerekir?

Çalışmada kullanılan bu soruların çözüm stratejileri olarak; "Eczacının Damacanaları” sorusu için Sistematik liste yapma stratejisi, “Irmak Kıyısındaki İki Kuş” sorusu için Değişken kullanma (Denklem kurma) stratejisi, "İşçiler” sorusu için Değişken kullanma (Denklem kurma) stratejisi, "Doğru-yalan” sorusu için Mantıksal akıl yürütme stratejisi ve "Kiralık Otomobil" sorusu için Geriye doğru çalışma stratejisi uzmanlar tarafından önerilmiştir.

\section{Çalışmanın Süreci}

İlköğretim matematik öğretmenliği son sınıfta seçmeli ders olarak okutulan “Zekâ soruları Yardımı ile Matematik Öğretimi” dersi kapsamında öğretmen adaylarıyla bir dönem boyunca Polya (1976)'nın problem çözme stratejilerinin kullanıldığı farklı zekâ ve mantık soruları çevrimiçi ortamda çözülmüş ve bu soruların ilköğretim matematik programında yer alan kazanımlar ile ilişkilendirilmeleri yapılmıştır. 12 haftalık çevrimiçi ders işleme sürecinden sonra öğretmen adaylarına 5 adet zekâ ve mantıksal düşünme becerilerini ölçebilecek açık uçlu sorular, çevrimiçi olarak planlanan bir ders sürecinde sorulmuş ve çözmeleri istenmiştir. Ayrıca bu soruların sınıflandırılmaları ile ilgili anket, soruların çözümünden sonra yine çevrimiçi olarak uygulanmış ve süreç tamamlanmıştır. Anket ve soru çözümleri yine çevrimiçi ortamda toplanmıştır.

\section{Verilerin Analizi}

Verilerin analizinde öğretmen adaylarının zekâ sorularını cevaplarken kullandıkları stratejileri belirlemek ve sınıflandırmak için nitel veri analizi tekniklerinden; betimsel ve içerik 
analiz yöntemleri kullanılmıştır. Betimsel analiz yöntemi, öğretmen adaylarının beş soru için kullandıkları çözüm stratejilerini frekans ve yüzde olarak ifade edilmesi için kullanılmıştır. Betimsel analiz tekniğinde, elde edilen veriler daha önceden belirlenmiş çerçevelere göre özetlenip yorumlanır (Yıldırım ve Şimşek, 2008). İçerik analizi yöntemiyle de öğretmen adaylarının verdikleri cevaplar, kullandıkları çözüm stratejileri doğrultusunda aşamalı puanlama yöntemiyle değerlendirilmiştir. Çalışmada kullanılan aşamalı puanlama ölçeği iki kategoriden (Problemi anlama ve Probleme uygun strateji belirleme) oluşmaktadır. Bu iki kategorinin altında da her bir ölçütün en yüksek (3 puan) ve en düşük (0 puan) performansını tanımlayan dört ölçüt yer almaktadır. Ayrıca, çalışmada öğretmen adayları tarafından cevaplandırılan anketin analizinde, zekâ sorularının bilgi düzeyini ölçmedeki derecesi, önem derecesi ve kullanım sıklıkları, frekans ve yüzdeler alınarak hesaplanmıştır.

\section{Çalışmanın Geçerlilik ve Güvenirliği}

Nitel araştırmalarda detaylı kayıtların yapılması, toplanan bilgilerin doğru ve kapsamlı olması, araştırma esnasında ses kayıtlarının tutulması, araştırmada katılımcılardan alıntılara ekleme yapılmadan doğrudan verilmesi güvenirliği artıran etmenlerdir (Büyüköztürk, Kılıç Çakmak, Akgün, Karadeniz ve Demirel, 2017). Nitel araştırmalarda iç geçerlik, araştırmacının belirlemiş olduğu kategorilerin ve araştırmacının yorumlarının mevcut doğrularla örtüşüp gerçeği yansıtmasına bağlıdır (Yıldırım ve Şimşek, 2008). İç geçerlik, iki farklı kişinin elde edilen verileri inceleyip karşılaştırması ile artırılabilir (Büyüköztürk ve diğ., 2017). Bu nedenle de araştırmada elde edilen veriler iki farklı uzman tarafından incelenerek karşılaştırılmıştır. Araştırmanın analiz sonuçlarının güvenirliğinin hesaplanmasında ise öğrenci yanıtları iki araştırmacı tarafından kodlanmış ve analiz edilmiştir. İki araştırmacının analizlerinin uyuşma yüzdesi \%88 bulunmuştur. $\mathrm{Bu}$ da analizin güvenirliğinin yeterli düzeyde olduğunu göstermektedir. Şencan (2005), değerlendirme sonuçlarının güvenilir kabul edilebilmesi için puanlayıcılar arası uyuşma yüzdesinin \%75'ten fazla olması gerektiğini ifade etmiştir. Puanlayıcılar arası uyum, Miles ve Huberman’ın (1994) önerdiği (Görüş Birliği / (Görüş Ayrılığ + Görüş Birliği)) * 100 formülü ile hesaplanmıştır.

\section{Bulgular}

$\mathrm{Bu}$ bölümde çalışmanın amaçları doğrultusunda elde edilen veriler çözümlenerek yorumlanmıştır. 


\section{Öğretmen adaylarının, zekâ sorularını çözmedeki başarılarına yönelik bulgular}

Öğretmen adaylarının zekâ sorularını çözerken tercih ettikleri problem çözme stratejilerinin belirlenmesini amaçlayan bu çalışmada, çözümlerin doğruluk oranları hesaplanmıştır. Öğretmen adaylarının zekâ sorularına verdikleri cevaplar incelendiğinde; “Eczacının Damacanaları” sorusuna öğretmen adaylarının \%75’inin doğru, \%25’inin yanlış yanıt verdiği; “Irmak Kıyısındaki İki Kuş” sorusuna öğretmen adaylarının \%60’ının doğru yanıt verdiği, \%25’inin yanlış ya da eksik yanıt verdiği, \%15’inin ise boş bıraktıkları belirlenmiştir. “İşçiler” sorusuna öğretmen adaylarının \%80’inin doğru yanıt verdiği, \%20’sinin yanlış yanıt verdiği; “Doğru-Yalan” sorusuna öğretmen adaylarının \%35’inin doğru yanıt, \%45’inin yanlış yanıt verdiği, \%20’sinin ise boş bıraktıkları belirlenmiştir. "Kiralık Otomobil” sorusuna öğretmen adaylarının \%73’ünün doğru yanıt verdiği, \%27’sinin yanlış yanıt verdiği bulunmuştur. Öğretmen adaylarının matematiksel işlem gerektiren sorularda daha başarılı oldukları, akıl yürütme ya da mantıksal düşünme gerektiren sorularda ise daha az başarılı oldukları görülmüştür.

\section{Öğretmen adaylarının, zekâ sorularının bilgi düzeyini ölçmedeki derecesine} yönelik görüşlerine ilişkin bulgular

Öğretmen adaylarının her bir zekâ sorusunun bilgi düzeyini ölçmedeki görüşleri Grafik 1' de verilmiştir.

\begin{tabular}{|c|c|c|c|c|c|}
\hline & HİÇ & $\mathrm{AZ}$ & ORTA & ÇOK & $\begin{array}{c}\text { OLDUKÇA } \\
\text { ÇOK }\end{array}$ \\
\hline ECZACI & 0,00 & 5,88 & 35,29 & 50,00 & 8,82 \\
\hline IRMAK & 2,94 & 5,88 & 17,65 & 29,41 & 44,12 \\
\hline DOĞRU & 23,53 & 38,24 & 26,47 & 2,94 & 8,82 \\
\hline KİRALIK & 0,00 & 11,76 & 44,12 & 29,41 & 14,71 \\
\hline • İŞÇİLER & 0,00 & 5,88 & 23,53 & 61,76 & 8,82 \\
\hline
\end{tabular}

Grafik 1. Öğretmen adaylarının her bir zekâ sorusunun bilgi düzeyini ölçmedeki görüşleri

Grafik 1 incelendiğinde, çalışmaya katılan öğretmen adayları, bilgi düzeyini en fazla (oldukça çok = \%44,12) ölçen zekâ sorusunun "Irmak Kıyısındaki İki Kuş” olduğunu, "DoğruYanlış" zekâ sorusunun ise en az düzeyde (hiç = \%23,53) bilgiyi ölçtügünü ifade etmişlerdir. 
Öğretmen adaylarının, zekâ sorularının önemine (gereklilik) yönelik görüşlerine ilişkin bulgular

Öğretmen adaylarının her bir zekâ sorusunun önemine (gereklilik) yönelik görüşleri Grafik 2' de verilmiştir.

\begin{tabular}{|c|c|c|c|c|c|}
\hline \multirow[t]{2}{*}{$\begin{array}{r}60,00 \\
50,00 \\
40,00 \\
30,00 \\
20,00 \\
10,00 \\
0,00\end{array}$} & \multicolumn{2}{|c|}{ 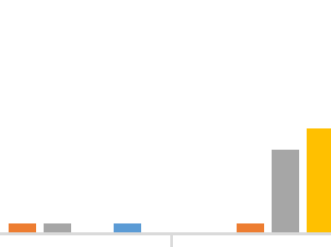 } & & & \\
\hline & HİÇ & $\mathrm{AZ}$ & ORTA & ÇOK & $\begin{array}{c}\text { OLDUKÇA } \\
\text { ÇOK }\end{array}$ \\
\hline - ECZACI & 0,00 & 0,00 & 52,94 & 35,29 & 11,76 \\
\hline - IRMAK & 2,94 & 2,94 & 20,59 & 44,12 & 29,41 \\
\hline DOĞRU & 2,94 & 23,53 & 38,24 & 20,59 & 14,71 \\
\hline KİRALIK & 0,00 & 29,41 & 26,47 & 35,29 & 8,82 \\
\hline • İŞÇİLER & 2,94 & 8,82 & 23,53 & 47,06 & 17,65 \\
\hline
\end{tabular}

Grafik 2. Öğretmen adaylarının, her bir zekâ sorusunun önemine (gereklilik) yönelik görüşleri Grafik 2 incelendiğinde, çalışmaya katılan öğretmen adayları, her bir zekâ sorusunun önemine (gereklilik) yönelik görüşleri incelendiğinde; en fazla (oldukça çok = \%29,41) öneme sahip zekâ sorusunun "Irmak Kıyısındaki İki Kuş” olduğunu, "Kiralık Otomobil” zekâ sorusunun ise en az öneme (hiç $+\mathrm{az}=\% 29,41$ ) sahip soru olduğunu ifade etmişlerdir.

Öğretmen adaylarının, zekâ sorularının kullanım sıklığına yönelik görüşlerine ilişkin bulgular 
YYÜ Eğitim Fakültesi Dergisi (YYU Journal of Education Faculty), 2021;18(2)582-604,http://efdergi.yyu.edu.tr,

Öğretmen adaylarının her bir zekâ sorusunun kullanım sıklığına yönelik görüşleri Grafik 3’ te verilmiştir.

\begin{tabular}{|c|c|c|c|c|c|}
\hline $\begin{array}{r}70,00 \\
60,00 \\
50,00 \\
40,00 \\
30,00 \\
20,00 \\
10,00 \\
0,00\end{array}$ & - & & & & - \\
\hline & Hİç & $\mathrm{AZ}$ & ORTA & ÇOK & $\begin{array}{c}\text { OLDUKÇA } \\
\text { ÇOK }\end{array}$ \\
\hline - ECZACI & 0,00 & 14,71 & 50,00 & 32,35 & 2,94 \\
\hline IRMAK & 2,94 & 8,82 & 17,65 & 38,24 & 32,35 \\
\hline DOĞRU & 2,94 & 20,59 & 58,82 & 5,88 & 11,76 \\
\hline KİRALIK & 8,82 & 17,65 & 20,59 & 44,12 & 8,82 \\
\hline • İŞÇİLER & 2,94 & 5,88 & 17,65 & 52,94 & 20,59 \\
\hline
\end{tabular}

Grafik 3. Öğretmen adaylarının, her bir zekâ sorusunun kullanım sıklığına yönelik görüşleri

Grafik 3 incelendiğinde, çalışmaya katılan öğretmen adayları, her bir zekâ sorusunun kullanım sıklığına yönelik görüşleri incelendiğinde; en fazla (oldukça çok $=\% 32,35$ ) kullanmayı düşündükleri zekâ sorusunun "Irmak Kıyısındaki İki Kuş” olduğunu, "Kiralık Otomobil” zekâ sorusunun ise en az kullanacakları (hiç = \%8,82) soru olduğunu ifade etmişlerdir.

Öğretmen adaylarının, zekâ sorularının çözümlerinde tercih ettikleri problem çözme stratejilerine ilişkin bulgular

Öğretmen adaylarının zekâ sorularını çözerken tercih ettikleri problem çözme stratejilerinin dağılımları Grafik 4' te gösterilmiştir. 


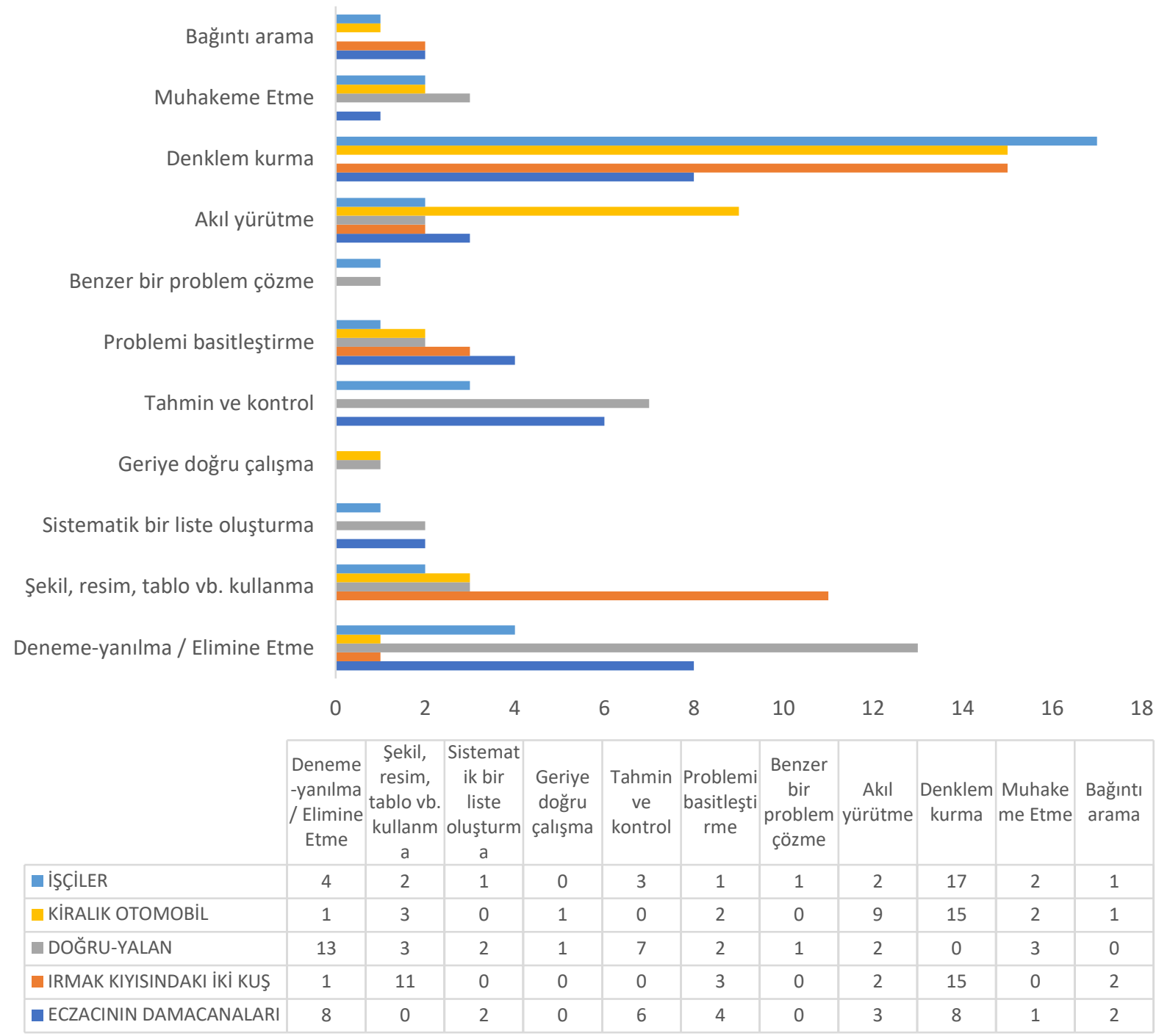

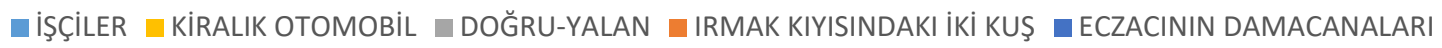

Grafik 4. Öğretmen adaylarının, zekâ sorularının çözümünde tercih ettikleri problem çözme stratejilerinin dağılımı

Öğretmen adaylarının zekâ sorularının çözümünde tercih ettikleri stratejiler Grafik 4’te özetlenmiştir. Grafik 4 incelendiğinde denklem kurma stratejisi baskın olarak kullanılırken, diğer stratejilerin kullanımının soruların türüyle ilişkili olarak değişim gösterdiği gözlemlenmektedir. Öğretmen adaylarının her soruda farklı stratejileri kullandığı da bulgularda saptanan bir durumdur.

Öğretmen adaylarının çözümleri incelediğinde, bazılarının çözüm için kullandıkları stratejileri isimlendirdikleri saptanmış fakat bu isimlendirmelerin bilinen isimlerinden farklı olarak ifade ettikleri tespit edilmiştir. Bu sonuç, öğretmen adaylarının kullandıkları stratejileri 
zihinlerinde tam olarak anlamlandıramadıkları göstermektedir. Öğretmen adaylarının soru çözümünde kendilerinin isimlendirdiği stratejiler Tablo 2’ de verilmiştir.

Tablo 2. Öğretmen adaylarının soru çözümünde kendilerinin isimlendirdiği stratejiler

- Stratejik düşünme stratejisi

- Oran ve orant1 yöntemi stratejisi

- Doğrudan çözüm stratejisi

- Değişken kullanma stratejisi

- Neden sonuç strateji
- Cebirsel ifadelere dönüştürme

- Oranlama yöntemi stratejisi

- Doğrudan çözüm stratejisi

- Pisagor bağıntısı stratejisi

- Model oluşturma stratejisi
- Bilinenden bilinmeyene öğretim yöntem ve tekniği stratejisi

- Bilinen bir bilgiyi kullanma stratejisi

- Analitik düşünme stratejisi

- Değişken Kullanma

- Araştırma inceleme stratejisi

\section{Tartışma ve Sonuç}

Çalışmada, ilköğretim matematik öğretmen adaylarının zekâ ve mantık sorularını çözerken kullandıkları stratejileri belirlemek ve sınıflamak amaçlanmıştır. Çalışma sonucunda, zekâ ve mantık sorularını çözerken öğrencilerin "Deneme-yanılma / Elimine Etme”, "Şekil, resim, tablo vb. kullanma”, “Sistematik bir liste oluşturma”, “Geriye doğru çalışma”, “Tahmin ve kontrol”, “Problemi basitleştirme”, “Benzer bir problem çözme”, “Akıl yürütme”, “Denklem kurma”, "Muhakeme Etme” ve "Bağıntı arama” stratejilerini kullandıkları, "İşlem seçme”, "Problemi başka bir biçimde ifade etme”, “Örüntü arama” ve "Varsayımları kullanma” stratejilerini ise hiç kullanmadıkları tespit edilmiştir. Çalışmada, öğrenciler tarafından en çok kullanılan stratejinin "Denklem Kurma” stratejisinin daha sonra da "Deneme-yanılma / Elimine Etme” stratejisinin olduğu tespit edilmiştir. Bu sonuç Uyar (2019)' in ve Taşpınar (2011)'ın çalışmalarıyla tutarlılık göstermektedir. Soyut düşünmenin başlamasına paralel olarak yedinci ve sekizinci sınıflardan itibaren kullanılan denklem yazma öğrencilerin en iyi kullandıkları stratejilerden biridir (Yazgan ve Arslan, 2017). Öğrenciler denklem kurma stratejisine aşina oldukları için bu stratejiyi tercih etmiş olabilirler. Cevizci (2020) çalışmasında öğretmenler görüşleri incelenmiş ve öğrencilerinin en çok kullandıkları stratejinin Tahmin ve Kontrol Stratejisi olduğunu belirlenmiş̧tir. Bu stratejiyi Muhakeme Etme Stratejisi takip etmiştir. Altun ve Arslan (2006) yedinci sınıf öğrencilerinle yaptıkları çalışmada tahmin ve kontrol (\%56), şekil çizme (\%24), problemi basitleştirme (\%23) stratejilerinin kullanıldığı sonucuna varmıştır. Seçtikleri altı strateji arasından öğrencilerin en fazla kullandıkları stratejileri bizim çalışmamızı 
destekler niteliktedir. Diğer stratejilerin farklılık göstermesinin sebebi ise bu çalışmada daha çok sayıda stratejiye yer vermiş olmamız olabilir. Öğrencilerin soruları çözerken en az kullandıkları stratejilerden birisi "Sistematik Liste Yapma” stratejisi olmuştur. Bu sonuç Arslan ve Altun (2007) ve Yıldız, Baltacı, Kurak ve Güven (2012)'nin çalışmalarıyla tutarsızlık göstermektedir. Araştırma kapsamında sorulan sorularda "Sistematik Liste Yapma" stratejisinin daha az kullanılma nedeni soruların yapısından kaynaklanabilir. Çünkü bazı gerçek hayat problemlerinde problem durumuna özgü tek sayıda olası sonuç olup bunu listelemek mümkün olmayabilir.

Çalışma sorularından biri olan "Doğru-Yalan”, sorusuna öğretmen adaylarının \%35’i doğru, \%45’i yanlış yanıt vermiştir. Sorunun çözümü için kullanılan stratejiler incelendiğinde iki kişi akıl yürütme ve üç kişide muhakeme etme stratejilerini kullanarak çözüme ulaşmaya çalışmış fakat üç kişi doğru sonuca ulaşmıştır. Burada dikkat çeken nokta, akıl yürütme ve muhakeme etme stratejisi kullanılarak çözülmesi beklenen bu soruya farklı stratejilerle yaklaşılmış olmasıdır ve bunlarda \%35 gibi düşük başarı sağlamıştır. Muhakeme etme becerisi, ilköğretim düzeyindeki öğrencilere kazandırılması hedeflenen temel becerilerden biri olup problem çözme stratejilerinin tümü bu süreci içermektedir (Altun, 2016). Öğrencilerin zekâ sorularını çözerken muhakeme etme stratejisini az kullanmış olmaları, öğrencilerin temel becerilerden biri olan akıl yürütme becerisini de tam anlamıyla kazanmadıkları şeklinde yorumlanabilir.

Araştırma bulgularından, farklı problem çözme stratejilerinin her birinin zekâ ve mantıksal soruların çözümünde, problem çözme başarısı açısından birbirlerine katkıda bulunduğu söylenebilir. $\mathrm{Bu}$ nedenle öğrencilere problem çözme stratejileri öğretiminin yapılmasının, öğrencilerin zekâ ve mantıksal problemlerini çözme becerilerine katkısı olacağı açıktır. Öğretmen adaylarının akıl ve mantık yürütme stratejilerinin kullanıldığı sorulardan kaçındıkları ve bu sorulardaki başarılarının diğer stratejilerin kullanıldığı sorulara göre daha düşük olması, gelecekte doğacak problemlere zemin hazırlayacaktır. Bu nedenle, matematik öğretmeni adaylarına verilecek eğitimlerin içeriklerinin, akıl ve mantık yürütme stratejilerini kullanabilecekleri zekâ soruları/oyunları ve rutin olmayan problemlerle planlanmış olmaları önerilebilir. 


\section{Makalenin Bilimdeki Konumu}

Matematik ve Fen Bilimleri Eğitimi Bölümü/Matematik Eğitimi

\section{Makalenin Bilimdeki Özgünlüğü}

Yapılan bu çalışmada, ilköğretim matematik öğretmeni adaylarının zekâ ve mantık sorularını çözerken kullandıkları problem çözme stratejileri belirlenerek bunları tercih etme ve etmeme gerekçeleri incelenip, bir durum betimlemesi yapılmıştır. 21. yüzyıl öğrenme çıtıları düşünüldüğünde, matematiğin uygulamaları olarak sınıf dışındaki sorunları çözmek için mantıksal düşünmenin gerekliliği önem teşkil etmektedir. Özellikle de uluslararası sınavlardaki matematik sorularının nitelikleri incelendiğinde mantıksal problemlerin çokluğu dikkat çekmektedir. 2018 yılından beri uygulanan LGS sınavındaki nitelikli soruların çözümlerinde kullanılacak olan stratejilerin öğretilmesinin öğretmen adaylarının yetiştirecekleri öğrenciler için de önemli olması gerekçesiyle bu çalışmanın sonuçları, lisans programındaki matematik derslerinin problem çözme stratejilerinin kullanımlarına göre düzenlenmesi gerekliliğini ortaya çıkarmıştır.

\section{Kaynaklar}

Akay, H. (2006). Problem Kurma Yaklaşımı ile Yapılan Matematik Öğretiminin Öğrencilerin Akademik Başarısı Problem Çözme Becerisi ve Yaratıcılı̆̆ı Üzerindeki Etkisinin Incelenmesi. (Yayımlanmamış Doktora Tezi). Gazi Üniversitesi Eğitim Bilimleri Enstitüsü, Ankara.

Alessi, S. M., \& Trollip, S. R. (2001). Multimedia for learning methods and development (3rd ed.). Boston, Massachusetts: Allyn \& Bacon.

Altun, M. (2005). İlköğretim ikinci kademede matematik öğretimi (4.Baskı). Bursa: Alfa Basım Yayım.

Altun, M. (2016). Ortaokullarda (5,6,7 ve 8. Sınıflarda) Matematik Öğretimi. Bursa: Aktüel Yayınları.

Altun, M., Arslan, Ç. (2006). İlköğretim Öğrencilerinin Problem Çözme Stratejilerini Öğrenmeleri Üzerine Bir Çalışma. Uludă̆ Üniversitesi Eğitim Fakültesi Dergisi, XIX (1), 1-21.

Arslan, Ç. ve Altun, M. (2007). Learning to solve non-routine mathematical problems. İlköğretim Online, 6(1), 50-61. 
Biddlecomb, B., \& Carr, M. (2011). A longitudinal study of the development of mathematics strategies and underlying counting schemes. International Journal of Science and Mathematics Education, 9(1), 1-24.

Bottino, R. M., Ferlino, L., Ott, M., \& Tavella, M. (2007). Developing strategic and reasoning abilities with computer games at primary school level. Computers \& Education, 49(4), 1272-1286.

Bulut, Ş. (2013). Eğiten, Düşündüren ve Geliştiren Zekâ Soruları. Liya yayıncılık, İstanbul.

Büyüköztürk, Ş., Kılıç Çakmak, E., Akgün, Ö.E., Karadeniz. Ş. ve Demirel. F. (2017). Bilimsel araştırma yöntemleri. 17.Baskı, Ankara: Pegem Akademi.

Çepni, S. (2009). Araştırma ve proje çalışmalarına giriş, (Geliştirilmiş 4.Baskı), Trabzon: Pegema Yayıncilık.

Cevizci, A.B. (2020). Ortaokul Öğrencilerinin Problem Çözme Stratejilerini Kullanma Becerilerine Yönelik Öğretmen Görüşleri. Yüksek Lisans Tezi, Fırat Üniversitesi, Eğitim Bilimleri Enstitüsü.

Cotic, M., \& Zuljan, M. (2009). Problem-based instruction in mathematics and its impact on the cognitive results of the students and on affective-motivational aspects. Educational Studies, 35(3), 297-310.

Cumming, G. (2014). The New Statistics: Why and How. Psychological Science, 25(1), 7-29.

CUPM, (2004). Committee on the Undergraduate Program in Mathematics (CUPM): CUPM Curriculum $\quad$ Guide $2004 . \quad$ MAA, Washington, DC. https://www.maa.org/sites/default/files/pdf/CUPM/summary.pdf Erişim tarihi: 07.11.2020.

Ergün, E. (2018). Zekâ Oyunları Dersine Giren Öğretmenlerin Oyun Tercihleri ve Zekâ Oyunlarının Uygulanabilirliğinin İncelenmesi. Yüksek Lisans Tezi, Erciyes Üniversitesi, Eğitim Bilimleri Enstitüsü.

Fan, L. \& Zhu, Y. (2006). Representation of problem-solving procedures: A comparative look at China, Singapore, and US mathematics textbooks. Educational Studies in Mathematics an International Journal, 39, 491-501.

Heppner, P. P., \& Krauskopf, C. J. (1987). An information-processing approach to personal problem solving. The Counseling Psychologist, 15(3), 371-447.

Hayes, J.R. (1989). The complete problem solver (2nd ed.). Hillsdale, NJ: Lawrence Erlbaum Associates. 
YYÜ Eğitim Fakültesi Dergisi (YYU Journal of Education Faculty), 2021;18(2)582-604,http://efdergi.yyu.edu.tr,

Intaros, P., Inprasitha, M., \& Srisawadi, N. (2014). Students’ Problem-Solving Strategies İn Problem Solving-Mathematics Classroom. Procedia-Social and Behavioral Sciences, 116(1), 4119-4123.

Lowrie, T. \& Logan, T. (2006). Using spatial skills to interpret maps: Problem solving in realistic contexts. Australian Primary Mathematics Classroom, 12(4), 14-19.

Martinez, M. E. (1998). What is Problem Solving? The Phi Delta Kappan, 79(8), 605-609.

Miles, M. B. \& Huberman, A.M. (1994). Qualitative Data Analysis: An Expanded Sourcebook. ( $2^{\text {nd }}$ Edition). Calif.: SAGE Publications

National Center for Education Statistics (NCES), (2018). U.S. Department of Education Institute of Education Sciences, Trends in student performance: International trends in average scores. https://nces.ed.gov/pubs2020/2020009.pdf, Erişim Tarihi: 08.12.2020.

Nesin, A. (1989). Matematik ve Korku. İstanbul: Amaç Yayıncılı.

NCTM (2000). Principles and Standards for School Mathematics. Reston, Va. NCTM.

Pesen, C. ve Odabaş, A. (2000). Matematik Öğretimi. Konya: Mikro Yayınları.

Piaget, J. (1968). Six Psychological Studies. Anita Tenzer (Trans.), New York: Vintage Books.

Polya, G. (1973). How to solve it. Princeton, NJ: Princeton University Press.

Pope, D., Brown, M., \& Miles, S. (2015). Overloaded and Underprepared: Strategies for stronger schools and healthy successful kids. San Francisco: Jossey-Bass.

Reeff, J. P. (1999). New Assessment Tools for Cross-Curricular Competencies in the Domain of Problem-Solving. http://www.ppsw.rug.nl/ peschar/TSE.pdf Erişim tarihi: 11.11.2020.

Sanders, M. E., (2012). Integrative stem education as best practice. In H. Middleton (Ed.), Explorations of Best Practice in Technology. Design, \& Engineering Education. 2, 103117. Griffith Institute for Educational Research, Queensland, Australia. ISBN 978-1921760-95-2.

Şencan, H. (2005). Sosyal ve davranışsal ölçümlerde güvenirlik ve geçerlilik. Ankara: Seçkin Yayınc1lık.

Shapiro, B. J., \& O’ Brien, T. C. (1970). Logical thinking in children ages six through thirteen. Child Development, 41(3), 823-829. https://doi.org/10.2307/1127227

Stake, R. (1995). The art of case study research. Thousand Oaks, CA: Sage Publications.

Stanic, G.M.A., \& Kilpatrick, J. (1988). Historical perspectives on problem solving in the mathematics curriculum. In R.I. Charles \& E.A. Silver (Eds.), The teaching and 
assessing of mathematical problem solving (pp. 1-22). Reston, VA: National Council of Teachers of Mathematics.

Sumarmo, U. (2002). Alternatif Pembelajaran Matematika dalam Menerapkan Kurikulum Berbasis Kompetensi. Makalah pada Seminar Tingkat Nasional FPMIPA UPI.: Tidak Diterbitkan.

Sweller, J., Clark, R., \& Kirschner, P. A. (2010). Teaching general problem-solving skills is not a substitute for, or a viable addition to, teaching mathematics. Notices of the American Mathematical Society, 57, 1303-1304.

Taşpınar, Z. (2011). İlköğretim 8. Sınıf Öğrencilerinin Matematik Dersinde Kullandıkları Problem Çözme Stratejilerinin Belirlenmesi. Yayınlanmamış yüksek lisans tezi, Gazi Üniversitesi, Ankara.

Tobin, K. G., \& Capie, W. (1981). The development and validation of a group test of logical thinking. Educational and Psychological Measurement, 41, 413-423.

Tobin, K. G., \& Capie, W. (1982). Relationships between formal reasoning ability, locus of control, academic engagement and integrated process skill achievement. Journal of Research in Science Teaching, 19, 113-121.

Uyar, Z.E. (2019). Ortaokul 7.Sını Öğrencilerinin Matematiksel Modellemede Problem Çözme Stratejilerinin Incelenmesi. Yayınlanmamış yüksek lisans tezi, Atatürk Üniversitesi, Erzurum.

Widdiharto, R. (2004). Model-model Pembelajaran Matematika SMP. Yogyakarta: (PPPG) Matematika.

Yaman, S. (2005). Fen Bilgisi Öğretiminde Probleme Dayalı Öğrenmenin Mantıksal Düşünme Becerisinin Gelişimine Etkisi. Türk Fen Eğitimi Dergisi (TÜFED), 2(1), 56-70.

Yazgan, Y. ve Arslan, Ç. (2017). Matematiksel sıradışı problem çözme stratejileri ve örnekleri (3. bask1). Ankara: Pegem Akademi Yayıncılık.

Yıldırım, A. ve Şimşek, H. (2008). Sosyal bilimlerde nitel araştırma yöntemleri. Ankara: Seçkin Yayıncılık.

Yıldız, A., Baltacı, S., Kurak, Y. ve Güven, B. (2012). Üstün yetenekli ve üstün yetenekli olmayan 8. sınıf öğrencilerinin problem çözme stratejilerini kullanma durumlarının incelenmesi. Uludă̆ Üniversitesi Ĕ̆itim Fakültesi Dergisi, 25(1), 123-143. 


\section{Extended Summary}

\section{Introduction}

21st century learning outcomes occur when students deeply comprehend mathematical concepts and use logical thinking to solve problems outside the classroom as applications of mathematics (Sanders, 2012). Many studies show that thinking is necessary to learn most of the mathematics and science concepts taught in middle school, high school, and university (Tobin \& Capie, 1982). In addition, studies have emphasized that most of the students in secondary and high schools cannot use formal procedures in problem solving, so priority in education should be given to the development of students' problem solving and reasoning skills (Tobin \& Capie, 1982). Teaching mathematics aims to develop students' critical thinking, logical, systematic, and objective reasoning skills that reflect their honest, disciplined, and problemsolving skills in various fields (Widdiharto, 2004).

\section{Purpose of the Study}

Math is an abstract course which aims to provide students with abstract thinking and reasoning skills. The emergence or development of students' existing abilities can be ensured with intelligence and logic questions/games. The aim of our study is to identify and classify the strategies used by prospective mathematics teachers while solving intelligence and logic questions.

\section{Method}

The case study model, one of the qualitative research methods, was used in this study to determine which of the problem-solving strategies the students use while solving the intelligence questions. In line with this purpose, the study was conducted with 34 prospective teachers who were studying in the last year of the Primary School Mathematics Teacher Education Program and took the course “Teaching Mathematics with the Help of Intelligence Questions”. As data collection tools, 5 questions that were suitable for the purpose of the study were selected from the book called as "Eğiten, Düşündüren ve Geliştiren Zekâ Soruları" published by Bulut (2013), and in the evaluation of these questions, the "Teacher Opinion Survey for the Intelligence Lesson” developed by Ergün (2018) was used adaptively by the researcher.

\section{Findings and Discussion}

In the study, it was determined that the strategy used by the students most was the "Writing Equations” strategy and subsequently the "Trial-and-error / Elimination” strategy. This result is consistent with the studies of Uyar (2019) and Taşpınar (2011). In parallel with 
the beginning of abstract thinking, writing an equation, which has been used since the seventh and eighth grades, is one of the strategies that students use best (Yazgan \& Arslan, 2017). Students may have chosen this strategy because they are familiar with the writing equation strategy. One of the least used strategies by the students while solving the questions was the “Making Organised Lists” strategy. This result is inconsistent with the studies of Arslan and Altun (2007) and Yıldız, Baltac1, Kurak and Güven (2012). Within the scope of the research, the reason why "Making Organised Lists" strategy is used less in the questions may be explained with the structure of the questions. Because in some real-life problems, there is only one possible result specific to the problem situation, and it may not be possible to list it. From the findings of the research, it can be stated that each of the different problem-solving strategies contributes to one another in terms of intelligence and problem-solving success in solving logical questions (Posamentier \& Krulik, 2016). For this reason, it is clear that teaching problem-solving strategies to students will contribute to their intelligence and logical problemsolving skills.

EK 1: Zekâ Sorularının Bilgi/Önem/Kullanma Sıklık Düzeylerini Belirleme Anketi

\begin{tabular}{|c|c|c|c|c|c|c|c|c|c|c|c|c|c|c|c|}
\hline & \multicolumn{5}{|c|}{ BİLGİ DÜZEYİ } & \multicolumn{5}{|c|}{$\begin{array}{l}\text { ÖNEM DERECESİ } \\
\text { (GEREKLILIK) }\end{array}$} & \multicolumn{5}{|c|}{ KULLANMA SIKLIĞI } \\
\hline & .e. & \& & 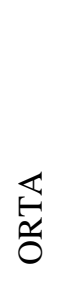 & 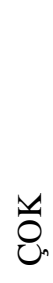 & 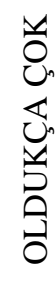 & 䚄 & \& & 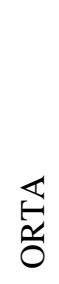 & 苂 & 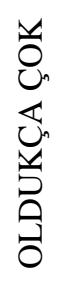 & 咭 & 幽 & 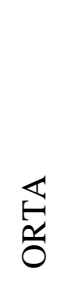 & 苑 & 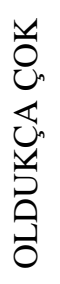 \\
\hline $\begin{array}{l}\text { ECZACININ } \\
\text { DAMACANALARI }\end{array}$ & & & & & & & & & & & & & & & \\
\hline $\begin{array}{l}\text { IRMAK KIYISINDAKI } \\
\text { İKI KUŞ }\end{array}$ & & & & & & & & & & & & & & & \\
\hline DOĞRU-YALAN & & & & & & & & & & & & & & & \\
\hline KIRALIK OTOMOBİL & & & & & & & & & & & & & & & \\
\hline İŞÇíLER & & & & & & & & & & & & & & & \\
\hline
\end{tabular}

